\section{THEORÍA}

REVISTA DEL COLEGIO DE FILOSOFÍA
NÚMERO 41 | DICIEMBRE 2021 - MAYO 2022 | 229-235

DOI: $10.22201 /$ ffyl.16656415p.2021.41.1698

Traducciones, reseñas y notas

\title{
INSTANTÁNEAS SOBRE EL ASOMBROSO CONCEPTO DE HABITAR
}

María Noel LAPOUJADE

Universidad Nacional Autónoma de México | México

Contacto: maria.noel.lapoujade@gmail.com

$\mathrm{L}$ os usos del término habitar en el habla brindan unas primeras pistas interesantes. Los hablantes no decimos "habitar una tumba", "habitar un campo de concentración", "habitar una prisión", "habitar un manicomio", "habitar un hospital", etcétera. En uno de los sentidos, el verbo habitar del cual formamos el concepto implica una acción, una acción de vivir en un lugar, de estar vivo. La primera condición sine qua non es estar vivo. Además, se trata de un lugar permanente y no circunstancial. El habitar implica la Vida.

El lugar es otro tema para reflexionar. Ocupar un lugar, provenir de un lugar, abre el tema del hábitat. Si retrocedemos un paso más, todo ello nos conduce a plantearnos la problemática crucial del espacio, en rigor, del espacio-tiempo. Obviamente, la complejidad y alcances de esta problemática quedan fuera de toda discusión viable.

Mi propósito es sembrar interrogantes a través de una trama de instantáneas; proponer un abanico de sentidos e interrogantes del concepto de habitar en función de mi noción de homo imaginans. Introduje esta noción en 1988 en mi primer libro: Filosofía de la imaginación. Ella se ha convertido en el pivote, el nervio conductor de mi pensamiento hasta la fecha, en cuyo lapso se ha ido afinando, ampliando, profundizando (Lapoujade, 1988: 193). Defino al ser humano como de la especie homo imaginans, que significa la especie humana entendida como bio-psico-socio-cósmica- imaginante (Lapoujade, 2014). En lo que sigue, nos asomamos muy brevemente a la noción de habitar en cada uno de estos campos.

\section{I}

El ámbito biológico abre un conjunto de interrogantes y respuestas a la pregunta ¿cómo entender habitar en este campo? Aquí irrumpe la geografía como conjunto de áreas del habitar espacios en la tierra: el tema de los entornos geológicos, climas, etnologías. La especie humana habita todas las geografías y todos los climas: los la- 
pones en el norte, los habitantes de Tierra del Fuego al sur, y todas las geografías incluidos los trópicos. Pero si nos aproximamos un paso más, surge la pregunta por los orígenes de esta especie, cuál fue su hábitat originario. Entonces nos deslizamos al fascinante campo de la genética (Porro, 2001).

¿De dónde viene la actual especie Homo sapiens? La paleogenética agudiza la mirada hacia el interior de las células de los fósiles, se introduce en el núcleo, y allí se encuentra con los cromosomas, sede del ácido desoxirribonucleico (ADN). Este universo en el seno de un micro-espacio, abre el tema de la procedencia geográfica de la especie actual, algún punto de África, en su hábitat prehistórico, y el comienzo de sus migraciones al Asia, a Europa y a América en consecuencia, sus mestizajes tales como neandertales y denisovanos entre otros; y sus mutaciones resultantes (Seinandre, 2005; Wells, 2007; Harari, 2018). Esta área de la genética con sus diversos campos introduce una revolución en la noción del habitar (Cavalli-Sforza, 2010; Pääbo, 2018)

El homo imaginans exhibe el esplendor y el ocaso de su psiquismo psicosomático. Por psíquico entiendo una vastísima problemática de nociones del habitar según las diversas psicologías y las neurociencias, sin olvidar la espiritualidad y aún la mística.

La especie se inserta en las más diversas geografías habitándolas. Pero las geografías habitan en los individuos. Su subjetividad, su mente, su espíritu son portadoras de sus hábitats geográficos. Bachelard (1994) afirma: "El bosque es un estado del alma" (171), el bosque nos habita, su paz, es una paz del alma. Más allá de Bachelard, considero que esta noción del habitar se fundamenta sobre la insostenibilidad de la dicotomía afuera-adentro como conceptos con límites rígidos. El afuera se interioriza, está adentro; el adentro se desparrama en la exterioridad. El habitar pone de manifiesto esta situación. En otro contexto, Deshimaru (1996) desde el Zen afirma: "El Zen es experiencia no limitada a una visión dualista de los fenómenos. Si contemplamos una montaña, por ejemplo, podemos contemplarla desde el ángulo objetivo, analizarla científicamente, hacerla entrar en las categorías del discurso. Pero en Zen nos convertimos en montaña" (3).

$\mathrm{Si}$ ahora enfocamos solamente los espacios en la subjetividad, ellos albergan los más diversos modos de habitar, de vigilia y sueño, del ensueño, del deseo, de la memoria, y todos ellos enhebrados por la Penélope del psiquismo humano: la imagi- 
nación y sus imágenes. Espacios exteriores, como los lugares en que está cada lector, y espacios vividos por cada uno, ¿cuántos hay en este instante aquí y ahora? (Lapoujade, 1999: 7-13, 15-18, 103-115). ¡Sí que es sorprendente la infinitud contenida en la noción de habitar!

\section{III}

El habitar se investiga desde ángulos sociológicos, históricos, filosóficos, antropológicos, pedagógicos, culturales, etcétera. Todas estas perspectivas constituyen aspectos relevantes de las sociedades y las relaciones interpersonales en nuestros días. En la actualidad, hay un predominio de lo que he llamado "sociedades gaseosas" (Lapoujade, 2017b). En el estado gaseoso, las partículas que componen el gas, con una fuerza de atracción casi inexistente, los átomos y moléculas se encuentran muy separados unos de otros, es decir, con baja densidad. Las partículas se mueven a altas velocidades y en cualquier dirección. Las sociedades gaseosas actuales, más allá de la diversidad cultural, étnica, política, religiosa, educativa, creencias y prejuicios, todas exhiben esa característica de atravesar un estado caótico, con una muy problemática cohesión social: sociedades muy convulsionadas. Los átomos en las sociedades gaseosas son los corpúsculos espacio-temporales, reductibles a puntos-instantáneos, metáfora de los individuos: singularidades diversas, dispersas, sueltas y sin cohesión.

Desde el punto de vista temporal, la sucesión de instantes tal como propone Gaston Bachelard ha pulverizado la duración, en el sentido de Henri Bergson (Lapoujade, 2011: 29-33, 57-62; Bachelard, 1932). Más aún, todo es efímero en su vertiginosa aparición y desaparición, tanto en las cosas (es el predominio de desechable sobre lo duradero) como en las relaciones interpersonales - fortuitas, pasajeras, inestables- en que la solidez del "para siempre" en cualquier orden de la vida (habitación, relaciones personales, trabajo) resulta obsoleta, ante los cambios abruptos donde parece que todo "vale" en el caos violento de las sociedades.

Además, con la pandemia, las sociedades sumidas en la enfermedad colectiva mundial - al respecto evoco la sabiduría de Empédocles (Les penseurs grecs avant Socrate, de Thalès de Milet à Prodicos, 1993) - muestran el predominio de las fuerzas del odio, la separación, la desunión, imperio de la fealdad, lo monstruoso, lo deforme. Estas sociedades difícilmente se unen con la tan olvidada fuerza de unión, la 
fuerza del amor y la belleza, es decir, el "disolvente universal de los problemas" según el alquimista Émile-Jules Grillot de Givry (2001: 23).

Dejémonos contagiar por la certeza de Dostoievsky quien en El idiota afirma: "La belleza salvará al mundo" (Dostoievsky, 2015: 7065).

\section{IV}

El homo imaginans vive en su hábitat cósmico. En estos días aciagos, el ser humano se ha olvidado que es un ser cósmico. Se ha olvidado que es un ser ínfimo, que no llega a ser ni siquiera un grano del polvo cósmico, se ha olvidado ni más ni menos que de su hábitat que sostiene a nuestra especie. Estos habitantes del planeta tierra, los Micromegas de Voltaire, han lastimado y extenuado el planeta, su hogar en el cosmos (Lapoujade, 2017a: 272-280).

Michel Serres ha acuñado la expresión "acosmismo", es decir el vivir como si nada tuviéramos que ver con el cosmos. Por su parte, Augustin Berque señala el "cosmos enfermo" de la humanidad actual (Berque, 2011; Serres, 2011). Cada individuo en el caos de sus sociedades gaseosas olvida que el ser humano es humus que vive pegado a la tierra. Con ella gira las 24 horas y los 365 días en torno al sol. Su sistema solar habita la galaxia, que a su vez gira a altas velocidades en torno a su centro, en torno a otros sistemas y otras galaxias, a la antimateria, los agujeros negros y los misterios que se abren más allá (Lapoujade, 2011: 106-108; Lapoujade, 2002: 19-40).

\section{V}

La especie humana es bio-psico-socio-cósmica, imaginante. Desde 1975 he emprendido ininterrumpidas búsquedas sobre la imaginación y los imaginarios, rasgos inherentes a lo humano. La imaginación produce imágenes, materia prima de las metáforas, signos, símbolos, alegorías, parábolas y mitos, dentro de un campo complejo. He constatado que, así como existe la imaginación y sus imaginarios sanos, también es posible encontrar la imaginación y sus imaginarios destructivos, enajenados y enfermos (Lapoujade, 2009: 169-182). El homo imaginans comparte los contrarios coexistentes: el día y la noche, el verano y el invierno, la luz y la oscuridad, la vigilia y el sueño, la conciencia y lo inconsciente, lo bueno y lo malo, lo bello y lo feo, la salud y la enfermedad, impulsos de vida y de muerte, luz y oscuridad de lo humano. 
Razonemos por el absurdo: ¿es pensable la especie sin la imaginación? La pregunta retórica pone de manifiesto la respuesta negativa. No hay especie humana sin alguna clase de imaginación. En mi perspectiva filosófica he enfatizado la imaginación y los imaginarios conducentes a la vida en todos los tiempos. Difícilmente puede pensarse la supervivencia de los neandertales sin el papel de la imaginación en sus mestizajes con los sapiens, en sus diferentes hábitats geográficos, que hasta hoy sobreviven en el genoma humano actual. El peligro y las amenazas de su medio ambiente tuvieron que exigirle a esa especie desarmada en y ante su hábitat, frecuentemente hostil, la vertiginosidad de los procesos imaginarios inmediatos, intuitivos, y no los lentos razonamientos inductivos o deductivos, conducentes a alguna conclusión, quizás lógicamente válida, pero inoperante, para posteriormente decidir cómo actuar voluntariamente. No habría tenido tiempo para desplegar semejantes trabajos de la razón.

Por otra parte, la imaginación en la prehistoria ha quedado plasmada en imágenes, pintadas en las paredes y techos de su hogar y las cavernas. La pintura rupestre más antigua consta de rayas. Se encuentran además puntos y figuras geométricas que se despliegan en las pinturas de los animales de su hábitat, de su entorno, y mucho más, imposible de abarcar aquí. Su hábitat y su vida son descritos en imágenes.

El hábitat cósmico hoy está en crisis, una crisis cuya salida exige recuperar el cosmos perdido. Como sostiene Taisén Deshimaru desde el Zen: "Sólo podremos resolver la crisis de nuestra civilización, armonizándonos con el orden y la energía del cosmos" (Deshimaru, 1996: 194; Lapoujade, 2020: 26-27). La sabiduría china antigua expresada en el pensamiento de Lao Tsé enseña que es preciso "seguir la ley del cielo" que rige todas las formas de vida. El pensamiento de Gaston Bachelard señala un camino para recuperar la memoria de la cosmicidad perdida. Para concluir, dejo resonar su afirmación "El mundo es bello antes de ser verdadero. El mundo es admirado antes de ser verificado" (Bachelard, 1943: 216; Lapoujade, 2011: 23-28; Lapoujade, 2013: 42-52).

\section{Referencias bibliográficas}

Bachelard, Gaston. (1932). L'intuition de l'instant. Étude sur la Siloë de Gaston Roupnel. Stock.

BaChelard, Gaston. (1943). L'air et les songes. Essai sur l'imagination du mouvement. Librairie José Corti. 
Bachelard, Gaston. (1994). La poétique de l'espace. Presses Universitaires de France.

Berque, Augustin. (2011). "La place de l'homme dans le cosmos. Cosmos malade?" Philosophie Magazine, 38-40.

Cavalli-Sforza, Luigi. (2010). Genes, Pueblos y lenguas. Editorial Crítica.

De Givry, Émile-Jules Grillot. (2001). La gran obra. Doce meditaciones sobre la vía esotérica al Absoluto. Editorial Yug, Matías Romero.

Deshimaru, Taisén. (1996). La práctica del Zen. Kairos.

Dostoıevskr. (2015). El idiota (Juan López-Morillas, Trad.). Epublibre.

Harari, Yuval Noah. (2018). De animales a dioses. Penguin Random House.

Lapoujade, María Noel. (1988). Filosofía de la imaginación. Editorial Siglo XXI.

LAPOUJADE, María Noel (Comp.). (1999). Espacios Imaginarios. FFyL; UNAM.

Lapoujade, María Noel. (2002). “Tiempos cósmicos y transgresiones imaginarias”. En María Noel Lapoujade (Comp.), Tiempos imaginarios: ritmos y ucronías (pp. 1940). FFyL; BUAP.

Lapoujade, Noel. (2009). Una estética de la salud. Revista Realidad, 119, 169-182.

Lapoujade, María Noel. (2011). Diálogo con Gaston Bachelard acerca de la poética. Universidad Nacional Autónoma de México.

Lapoujade, María Noel. (2013). "Propuesta bachelardiana acerca de la objetividad". Revista de Filosofía de la Universidad de Costa Rica, 52(133), 45-52.

Lapoujade, María Noel. (2014). Homo Imaginans. Benemérita Universidad Autónoma de Puebla.

Lapoujade, María Noel. (2017a). Homo Imaginans II. Benemérita Universidad de Puebla.

Lapoujade, María Noel. (2017b). "Salud en las sociedades gaseosas. Health in gaseous societies”. Revista Ciencias Psicológicas, 11(2), 247-251.

Lapoujade, María Noel. (2020). "El Zen como filosofía de vida". Revista Relaciones, 435, 26-27. 
LES PENSEURS grecs avant Socrate, de Thalès de Milet à Prodicos (Jean Voilquin, Trad.). (1993). Garnier-Flammarion.

РёÄво, Svante. (2018). El hombre de Neandertal, En busca de genomas perdidos. Alianza Editorial.

Porro, Magdalena. (2001). La genética. El código de la vida. Compendio Longseller.

SEINANDRE, Erick. (2005). Los orígenes del hombre: ¿De dónde venimos? Larousse.

Serres, Michel. (2011). “Le paysage du monde”. Philosophie Magazine, 9-11.

WELls, Spencer. (2007). El viaje del hombre. Una odisea genética. Editorial Océano.

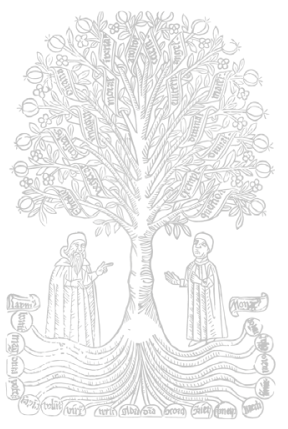

